\title{
原著 III
}

\section{Cronkhite-Canada 症候群に大腸癌を合併した 1 例}

\author{
大分市医師会立アルメイダ病院外科 \\ 板橋道朗山市病理 \\ 森内昭 \\ 東京女子医科大学第 2 外科
}

亀岡伸悟浜 野恭一

症例は78歳, 女性. 下痢, 食思不振, 体重減少を主訴に来院した. 来院時, 皮膚色素沈着, 脱毛, 爪甲の 変形を認めた. 上部消化管内視鏡検查にて胃全域に多発性ポリープを認め，組織学的には過形成性ポリープ であった．注腸造影および大腸内視鏡検査で $\mathrm{S}$ 状結腸に全周性の狭窄を伴う 2 型の $\mathrm{S}$ 状結腸癌が確認され， 大腸にはポリープが散在していた，以上よりS状結腸癌を合併した Cronkhite-Canada 症候群の診断でS 状 結腸切除術を施行した．組織学的には低分化型腺癌であった．また，大腸のポリープの一部に腺腫様変化が 混在していた，術後経過は良好で退院した。われわれが検索した限りでは, Cronkhite-Canada 症候群に大腸 癌を合併した本邦報告例は1992年 4 月までに15例に過ぎず稀であったため，若干の文献的考察を加え報告し た.

索引用語 : Cronkhite-Canada 症候群, 大腸癌, 消化管ポリポーシス

Cronkhite-Canada 症候群は，広範な消化管ポリポー シスに皮䖉色素沈着，脱毛，爪甲異常などの外杯葉系の 異常を伴い，中年以降澄症する非遺伝性疾患である. われわれは, Cronkhite-Canada 症候群にS 状結腸癌を 合併した稀な 1 例在経験したので若干の文献的考察を加 え報告する。

\section{症 例}

症 例: 78歳, 女性.

主 訴: 下唎, 食思不振, 体重減少.

家族歷：特記すべきことなし.

既往歴：昭和62年右変形性膝関節症.

現病歷: 平成 3 年 5 月頃より食思不振, 下䠔が出現し たが放置していた，体重減少拉よび全身倦意感が著明と なったため 9 月 4 日近医を受診した。胃内視鏡検査で胃 多発性ポリープを指摘され精查目的のため当院内科を紹 介され，Chronkhite-Canada 症候群の疑いで入院とな った.

入院時現症：身長 $145 \mathrm{~cm}$, 体重 $45 \mathrm{~kg}$, 脈拍 $70 /$ 分, 整, 血厈108/60mmHg．分血，黄瘟は認めないが，栄養状
態は不良であった。皮膚色素沈着，脱毛，爪甲の変形を 認めた（図 1 ），腹部膨満が中等度認められたが，腫瘤 は触知しなかった。

大院時検查成績; 白血球数が $13400{ }^{\prime} \mathrm{mm}^{3}$ と増加, 血 清総蛋白 $4.8 \mathrm{~g} / \mathrm{dl}$, アルブミン $2.8 \mathrm{~g} / \mathrm{dl}$ と低蛋白血症を認 めた. また, CEA は4.0ng/dI (正常值 $5.0 \mathrm{ng} / \mathrm{ml}$ 以 下)であっ(表 1 ).

上部消化管内視鏡検查; 胃粘膜贸壁の発赤, 肥厚とと もにほぼ全域に赤色調の山田 $\mathbf{I} 〜$ II 型の大小不揃いのポ リープが多数観察された. 数カ所ポリペクトミーを施行 したが, hyper plastic polyp であった. (図 2).

小腸二重造影検查; 異常を認めず，ポリープも存在し なかった.

注腸検査；S状結腸に全周性の狭窄を認め，造影剂は 僅かに口側に流入するのみであった（図 3).

大腸内視鏡検查； $\mathrm{S}$ 状結腸中央に全周性の狭窄示す 2 型の腫瘍が確認され，全大腸に赤色調の強い山i田 I II 型の大小不同のポリープが散在していた（図 4). 生検 にて S 状結腸の腫瘤は腺癌であることが確認された. 同年10月28日頃より腹部膨満，発熱出現し，S状結腸 


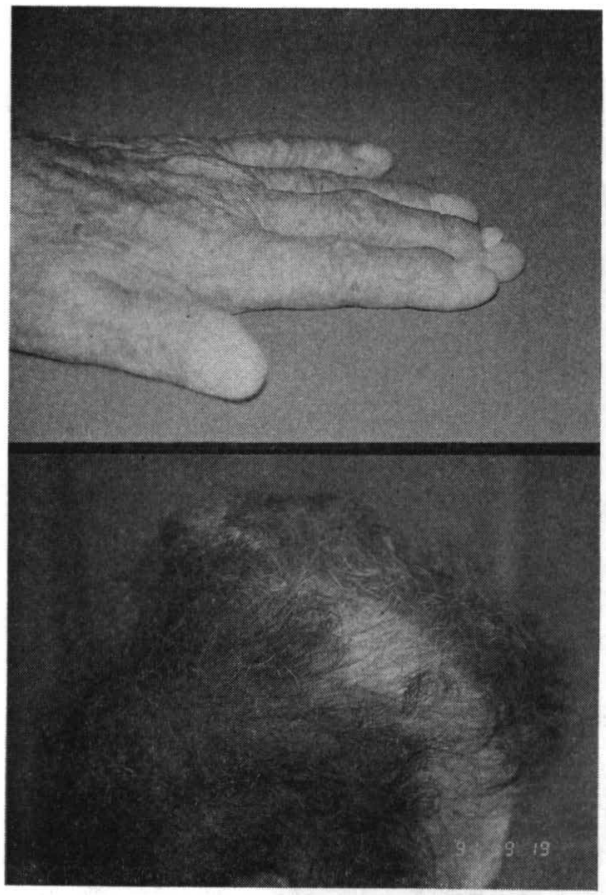

図 1

上; 爪甲の変形, 下; 著明な脱毛

\section{表 1 入院時検查所見}

\begin{tabular}{|c|c|c|c|}
\hline \multicolumn{2}{|c|}{ Blood analysis } & T. Bil & $0.3 \mathrm{mg} / \mathrm{dl}$ \\
\hline WBC & $13,400 / \mathrm{mm}^{3}$ & $\mathrm{ChE}$ & $0.43 \triangle \mathrm{pH}$ \\
\hline \multicolumn{2}{|c|}{$\mathrm{RBC} 398 \times 10^{4} / \mathrm{mm}^{3}$} & BUN & $26 \mathrm{mg} / \mathrm{dl}$ \\
\hline $\mathrm{Hb}$ & $12.6 \mathrm{~g} / \mathrm{dl}$ & Cre & $1.0 \mathrm{mg} / \mathrm{dl}$ \\
\hline $\mathrm{Ht}$ & $37.9 \%$ & $\mathrm{Na}$ & $138 \mathrm{mEq} / 1$ \\
\hline Plt & $36.1 \times 10^{4} / \mathrm{mm}^{3}$ & K & $3.2 \mathrm{mEq} / 1$ \\
\hline \multicolumn{2}{|c|}{ Blood chemistry } & $\mathrm{Cl}$ & $97 \mathrm{mEq} / 1$ \\
\hline $\mathrm{TP}$ & $4.8 \mathrm{~g} / \mathrm{dl}$ & \multicolumn{2}{|c|}{ Tumor marker } \\
\hline $\mathrm{Alb}$ & $2.8 \mathrm{~g} / \mathrm{dl}$ & CEA & $4.0 \mathrm{ng} / \mathrm{ml}$ \\
\hline GOT & $22 \mathrm{IU} / \mathrm{L}$ & AFP & $3 \mathrm{ng} / \mathrm{ml}$ 以下 \\
\hline GPT & $16 \mathrm{IU} / \mathrm{L}$ & CA19-9 & $9122 \mathrm{U} / \mathrm{ml}$ \\
\hline
\end{tabular}

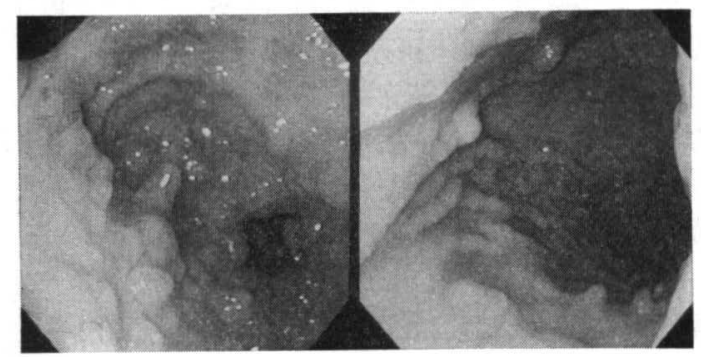

図 2 胃内視鏡所見

大小不揃いの多発性ポリープを認める.

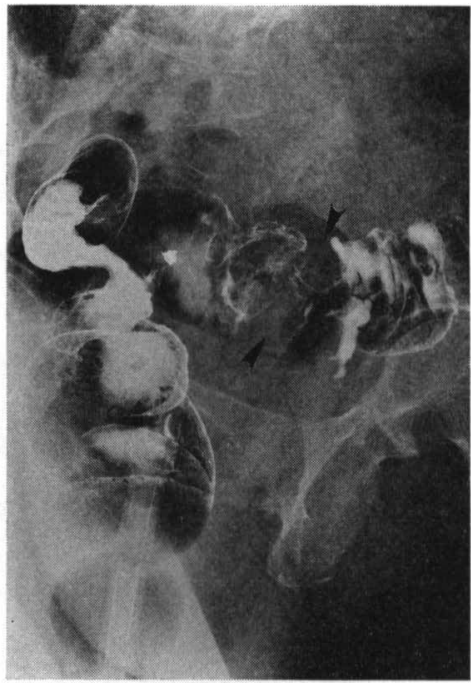

図 3 注腸造影

$\mathrm{S}$ 状結腸に apple core sign を認める。

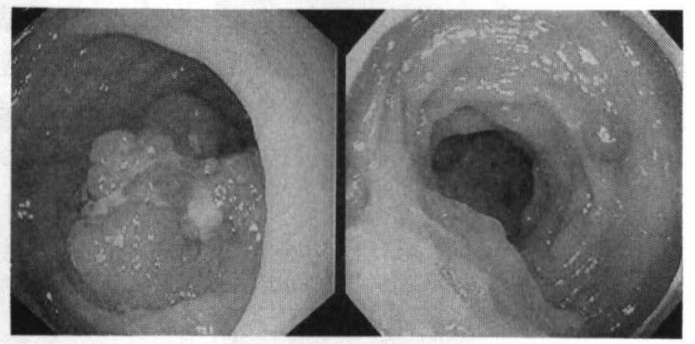

図 4 大腸内視鏡所見

左； S 状結腸癌，右 ; 散在するポリープ

癌による閉塞性大腸炎の診断で平成 3 年 10 月 31 日外科転 科, 同日横行結腸に人工肛門造設術を施行した。 術後 心不全を併発したが軽快, その後プレドニン $(5 \mathrm{mg} /$ day，連日）を投与したところ，下痢症状が軽減し全身 状態および脱毛などの外杯葉系の症状が著明に改善した (図 5 )。これら外杯葉系の症状，全身状態の改善を待 ち，1991年1月21日 S 状結腸癌を合併した CronkhiteCanada 症候群の診断で人工肛門閉鎖， S 状結腸切除術 を施行した (図 6 ). 肝転移, 腹膜播種は認めず病理学 的所見は低分化型腺癌で, 壁深達度 $\mathrm{ss}, \mathrm{ly}_{2}, \mathrm{v}_{0}, \mathrm{n}_{3}(+)$ であった（図 7 ). 大腸のポリープも大部分が胃ポリー プも大部分が胃ポリープと同様の組織像を示したが, 一 部に腺腫様変化が混在していることが確認された(図8).

術後経過; 術後経過は良好で, プレドニン $5 \mathrm{mg} / \mathrm{day}$ 内服にて症状は安定しており, 平成 4 年 3 月 21 日退院し た. 術後 7 力月現在生存中である. 


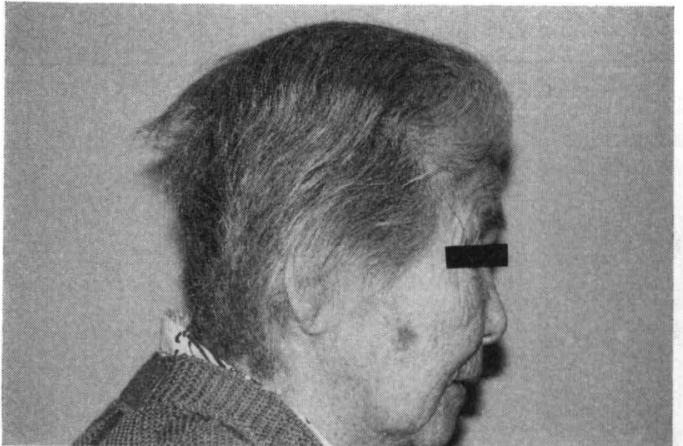

図 5 プレドニン投与後の頭髮の改善状態

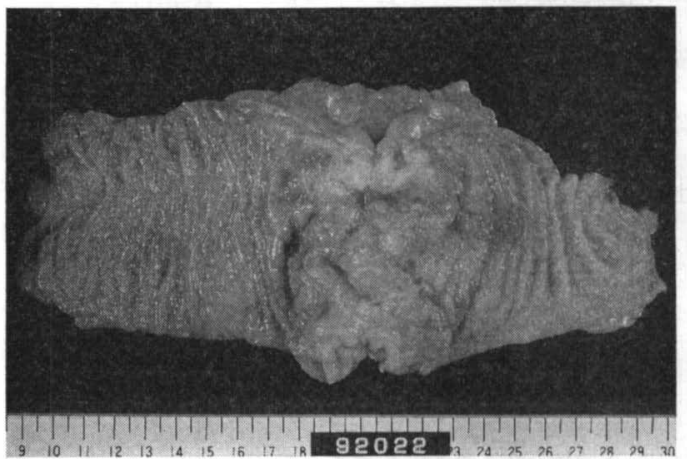

図 6 切除標本

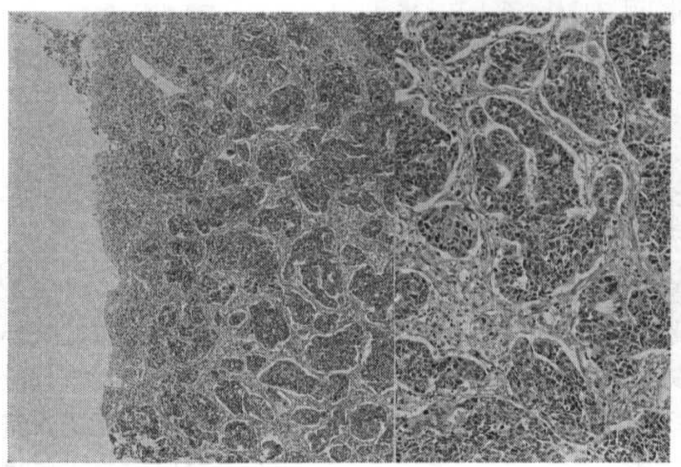

図 7 S 状結腸癌 (H-E 染色) 左; 弱拡大, 右; 強拡大

\section{考察}

Cronkhite-Canada 症候群は, 中年以降に発症する非 遺伝性ポリポーシスであり, 下痢, 食欲不振, 体重減少 などの症状で発症し, 皮膚色素沈着, 脱毛, 爪甲萎縮等 の特徴的な外杯葉系の異常をきたす疾患である.

Cronkhite と Canada が1955年にはじめて報告して

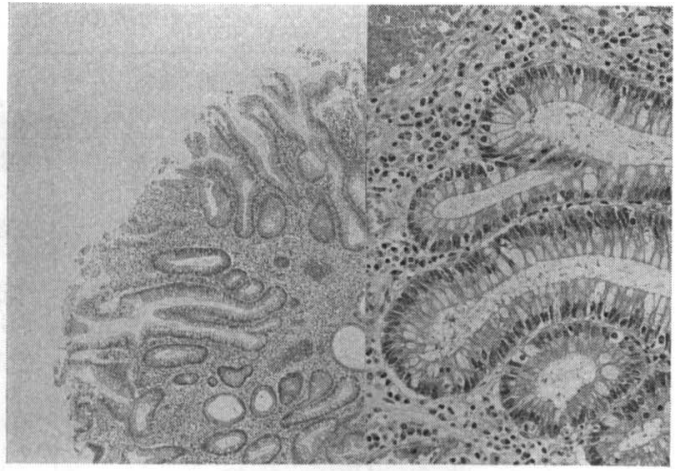

図 8 大腸ポリープ (H.E 染色) 左; 弱拡大, 右; 強拡大

以来1)，1986年末までに世界で165症例の報告があり，そ のうち本邦からの報告は 123 例で全報告例の $2 / 3$ を占めて いる2). 性比ではやや男性に多いとされ ${ }^{3-5)}$, 発症時の年 齢は50歳代をピークとするなだらかな分布を示すといわ れている6)。初発時臨床症状は，下痢と体重減少を $90 \%$ 以上に, るいそう, 無力僚意感, 浮腫, 腹部膨満を $60 \%$ 以上に認めると 報告されている7). Cronkhite-Canada 症候群に特徴的な外杯葉系の症状では爪の変化がほぼ全 例に認められ, 脱毛, 色素沈着も頻度が高い.

Cronkhite-Canada 症候群のポリープは全消化管に発 生するとされているが, 大部分の症例は胃, 十二指腸, 小腸, 大腸に発生し，とくに胃と大腸に頻度が高い. 本 症例も胃と大腸にポリープを認め, 外杯葉系の症状も典 型的であった.

本症候群の消化管ポリープは比較的短期間に減少また は消失することから, なんらかの炎症性や反応性の機序 か゚いわれている. Cronkhite らは，本症候群のポリー プについて adenomatous polyp と記載しているが，腺 管の囊胞状拡張と間質の浮腫を特徵とする juvenile polyp にきわめて類似した組織像を呈するのが特徴的所見 とされている8). このことから, 本症のポリープが癌化 することはまれであるとされてきた.

しかし，DaCruz により本症候群と癌の合併が報告さ れて以来 ${ }^{9)}$ ，本邦でも本症候群に大腸癌を合併した症例 報告が散見されるようになり, 癌合併の頻度は少なくと も10\%以上であるといわれている(10). 本邦における最初 の報告は1971年に笹川ら ${ }^{11)}$ の直腸癌合併例である. 1992 年 4 月までにわれわれが集計し得た本邦における大腸癌 合併例は自験例を含め16例であった（表 2 ），年齢は49 歳から78歳, 平均 60.4 歳で, 男女比は 13 対 3 と男性に多 かった. 大腸癌の占居部位は，直腸が 8 例 (50.0\%)， 
表 2 大腸癌を合併した Chronkheite-Canada 症候群の本邦報告例

\begin{tabular}{|c|c|c|c|c|c|c|c|c|}
\hline No. & $\begin{array}{l}\text { 報告者 } \\
\text { (年 度) }\end{array}$ & 症例 & $\begin{array}{r}\text { 大 } \\
\text { 発生部位 }\end{array}$ & $\begin{array}{l}\text { 腸 癌 } \\
\text { 組織学的所見 }\end{array}$ & 治療術式 & $\begin{array}{c}\text { ポリープの } \\
\text { 組織像 }\end{array}$ & 転 㷌 & 䊖 \\
\hline 1 & $\begin{array}{c}\text { 川111 } \\
\text { (1971年) }\end{array}$ & $59 \mathrm{M}$ & 直腸 & 腺癌 $(\mathrm{pm})$ & 大腸全摘術 & 腺腫性変化あり & 術後 2 週死亡 & \\
\hline 2 & 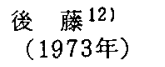 & $58 \mathrm{~F}$ & 直腸 & 腺癌（pm） & 直腸高位奵除術 & $\begin{array}{l}\text { 腺腫性ポリープ } \\
\text { 混在 }\end{array}$ & 術後 6 日死亡 & \\
\hline 3 & $\begin{array}{l}\text { 村 } \text { 山 }^{13)} \\
(1976 \text { 年 })\end{array}$ & $60 \mathrm{~F}$ & $S$ 状結腸 & 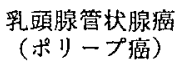 & $\begin{array}{l}\text { 内視鏡的 } \\
\text { ポリペクトミー }\end{array}$ & $(-)$ & $(-)$ & \\
\hline 4 & $\begin{array}{l}\text { 水 戸14) } \\
\text { (1977年) }\end{array}$ & $51 \mathrm{M}$ & 直腸 & 管状腺癌 & 直腸切断術 & 腺腫性変化なし & 術後 5 力月生存 & 術後症状楥解 \\
\hline 5 & $\begin{array}{l}\text { Nonomura } \\
(1980 \text { 年) }\end{array}$ & $78 \mathrm{M}$ & $\mathrm{S}$ 状結腸 & $\begin{array}{l}\text { 高分化腺癌 } \\
\text { (ss) }\end{array}$ & 手術施行せず & $\begin{array}{l}\text { 腺腫性ポリープ } \\
\text { 混在 }\end{array}$ & $\begin{array}{l}\text { 発症より } \\
\text { 約 } 9 \text { 力月死亡 }\end{array}$ & 剖検例 \\
\hline 6 & $\begin{array}{l}\text { 水 町 15) } \\
(1985 \text { 年 })\end{array}$ & $75 \mathrm{M}$ & 直晹 & $\begin{array}{l}\text { 高分化腺掂 } \\
\text { (ss) }\end{array}$ & 直腸切断術 & $\begin{array}{l}\text { 腺腫性ポリープ } \\
\text { 混在 }\end{array}$ & $\begin{array}{l}\text { 術後約 } 3 \text { 力月 } \\
\text { 死亡 }\end{array}$ & 直晹癌経過中発症 \\
\hline 7 & $\begin{array}{c}\text { Katayama } \\
(1985 \text { 年 })\end{array}$ & $52 \mathrm{M}$ & 直腸 & $\begin{array}{l}\text { 中分化腺㾔 } \\
(\mathrm{pm})\end{array}$ & $\begin{array}{l}\text { 全結腸直腸上部 } \\
\text { 切除術 }\end{array}$ & 腺腫性変化あり & $\begin{array}{l}\text { 術後 } 4 \text { 力月軽快 } \\
\text { 退院 }\end{array}$ & 術後症状緩解 \\
\hline 8 & $\begin{array}{l}\text { 内 } \begin{array}{c}\text { 藤 }^{177} \\
(1986 \text { 年 })\end{array}\end{array}$ & $62 \mathrm{M}$ & 下行結腸 & 高分化腺廐 & 右半結腸切除術 & 腺堙性変化あり & 㭪後 4 力月死亡 & $\begin{array}{l}\text { 術後 } 3 \text { 力月後に } \\
\text { 症状出現 }\end{array}$ \\
\hline 9 & $\begin{array}{l}\text { 武 田 }{ }^{18)} \\
\text { (1986年) }\end{array}$ & $62 \mathrm{M}$ & 盲腸 & 中分化腺灌 & 右半結腸切除術 & $\begin{array}{l}\text { 腺腫性ポリープ } \\
\text { 湿在 }\end{array}$ & $(-)$ & \\
\hline 10 & $\begin{array}{l}\text { 高 橋 } 191 \\
(1986 \text { 年) }\end{array}$ & $52 \mathrm{M}$ & 直腸 & 中分化腺癌 & $\begin{array}{l}\text { 全結腸直腸上部 } \\
\text { 切除衍 }\end{array}$ & 腺腎珄変化あり & 術後症状緩解 & \\
\hline 11 & 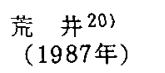 & $58 \mathrm{M}$ & $\mathrm{S}$ 状結晹 & $\begin{array}{l}\text { 中分化腺癌 } \\
(\mathrm{pm})\end{array}$ & $\mathrm{S}$ 状結腸切除術 & $(-)$ & $(-)$ & \\
\hline 12 & $\begin{array}{c}\text { 趙 21) } \\
\text { (1988年) }\end{array}$ & $52 \mathrm{M}$ & 直腸 & $\begin{array}{l}\text { 高分化腺疪 } \\
(\mathrm{pm})\end{array}$ & 直腸切断術 & 腺腫性変化あり & $(-)$ & \\
\hline 13 & 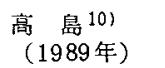 & $56 \mathrm{M}$ & 直腸 & $\begin{array}{l}\text { 中分化腺癌 } \\
(\mathrm{pm})\end{array}$ & 大腸全摘術 & 腺腫性変化あり & $\begin{array}{l}\text { 術後 } 2 \text { 年 } 6 \text { 力月 } \\
\text { 生存 }\end{array}$ & 術後症状緩解 \\
\hline 14 & $\begin{array}{c}\text { 田 } 221 \\
\text { (1990年) }\end{array}$ & $49 \mathrm{M}$ & $\mathrm{S}$ 状結腸 & $\begin{array}{c}\text { 管状腺癌 }(\mathrm{m}) \\
(\text { ポリープ) }\end{array}$ & $\begin{array}{l}\text { 内視鏡的 } \\
\text { ポリペクトミ- }\end{array}$ & 腺腫性変化あり & $\begin{array}{l}\text { ポリペクトミ- } \\
\text { 後8カ月健在 }\end{array}$ & \\
\hline 15 & 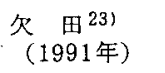 & $64 \mathrm{M}$ & 大腸 & $(-)$ & 手術 & $(-)$ & $(-)$ & $\begin{array}{l}\text { ステロイド療法にて } \\
\text { ポリープ消失後発見 }\end{array}$ \\
\hline 16 & $\begin{array}{l}\text { 自験例 } \\
\text { (1991年) }\end{array}$ & $78 \mathrm{~F}$ & $\mathrm{~S}$ 状結腸 & $\begin{array}{l}\text { 低分化腺曒 } \\
\text { (ss) }\end{array}$ & $S$ 状結腸切除 & 腺腫性変化あり & 術後 8 力月生存 & 術後症状緩解 \\
\hline
\end{tabular}

(一)：記載なし

$\mathrm{S}$ 状結腸が 5 例 $(31.3 \%)$ ，下行結腸よよび盲腸が各々 1 例，不明 1 例で，全症例の $87.5 \%$ 方左側結腸に癌を合 併した症例であった．治療は，大腸全摘術から内視鏡的 ポリペクトミーまでさまざまであった.

本症候群における癌の発生原因として，単なる偶発的 な癌の合併，ポリープからの癌化などが考えられてい る、われわれが集計した本邦報告例の大腸ポリープの組 織像は, 腺腫性ポリープの混在や腺腫性変化を認めた症 例が12例（75.0\%）に認められた．このことは本症に合 併した大腸癌の発生が，一般の大腸癌と同様に腺腫を介 して癌化した可能性が高いことを示唆している.しかし， 直腸癌術後に本症が発生した症例も報告されており，本 症と大腸癌が同様の原因で発症した可能性も否定できな い. 今後の検討が必要である.

本症の治療は，中心静脈栄養，経腸栄養，副腎皮質木 ルモンなどの栄養療法や薬物療法が行われ，著効例が報 告されているが, 癌合併例で注外科的治療を回避するこ
と注困難である，外科的治療としてはさまざまな術式が 行われているが，自験例では異ポリープは hyperplastic polyp であり，大腸ポリープは術前の副腎皮質ホルモン 投与により減少が見られたことおよび高龄であることか ら，予防的胃切除や大腸全摘は施行せず， S 状結腸切除 術のみ施行した。本症候群の癌合併嚬度が高いこと注諸 家の報告から明らかであるが，現時点では癌の根治術に とどめておくべきと考えている，しかし，左側結腸に癌 の合併頻度肪高く厳重な経過観察が必要と思われる。

\section{文献}

1) Cronkhite, LW, Canada WJ : Generalized gastrointestinal polyposis, pigmentation, alo. pecia and onychtrophia. New Eng J Med 252 : 1011-1015, 1955

2) 後藤明彦: Cronkhite-Canada 症候群の検封一 とくに本邦報告例123例の治療之予後にっ て一。目本外科宝图 $57: 427-433,1988$ 
3) Nonomura A, Ohta G, Ibata T : CronkhiteCanada syndrome associated with sigmoid cancer: Case re-port and review of 54 cases the syndrome. Acta Pathol Jpn $30: 825-845$, 1980

4) Nishiki M, Takasugi S, Kanao $M$, et al: Cronkhite-Canada syndrome-A case report and analytical review of 37 other cases reported in japan. Hiroshima. J Med Sci 33 : $607-614,1984$

5）市川正章, 川口新平, 斎藤古志ほか：Cronkhite-Canada 症候群の1剖検例，胃々腸 10 : 1519-1524, 1975.

6）鎌上孝子, 中村孝司, 合地研吾ほか：Cronkhite-Canada 症候群の 1 例. 帝京医誌 5 : 149-154, 1982.

7）後藤明彦，多羅尾信，船戸崇史ほか：Cronkhite.Canada 症候群 検討, とくに消化吸収障 害にっいて。伎阜大医紀 $36: 654-663 ， 1988$

8) 後藤明彦，味元宏道，下川邦泰ほか：特殊な消 化管ポリープー(3) Cronkhite-Canada 症候群. 臨床医学 $24: 341-348,1988$

9) DaCruz G M G : Generalized gastro-intestinal polyposis: An unusual syndrome of adenomatous polyposis, alopecia, onychotrophia. Am J Gastroenterol $47: 504-510,1967$

10）高島茂樹, 福永 純, 富田富士夫ほか：直腸澏 を合併した Cronkhite-Canada症候群の 1 例一 本邦報告例の集訫 と考察一. 消外 $14: 363$ 369,1991

11）笹川力, 木村 明, 高橋刷一ほか：直腸ポリ ープの悪性化を伴った Cronkhite.Canada 症 候群の1例。胃と腸 $6: 627-633,1971$

12）後藤明彦，下野和雄：Cronkhite-Canada 症候 群；とくに Peutz-Jeghers 症候群との異同につ いて。内科 $32: 742-747,1973$

13）村山広道, 森田敏和, 姉小路公久ほか：結腸ポ
リープ澞を合併した Cronkhite-Canada 症候 群の1例。日消病会誌 $73: 153-153,1976$

14）水兵省，三浦正悦，大泉晴史ほか：直腸癌を 合併し，手術後著明な緩解を示した Cronkhite-Canada症候群の1例。胃と腸 12:489493, 1977

15）水町信行, 滝紀雄, 川㥓康彦ほか：直晹癌経 過中に発生した Cronkhite- Canada 症候群の 1 例. 胃と腸 20 : 1033-1040，1985

16) Katayama $Y$, Kimura $M$, Konn $M$ : Cronkhite-Canada syndrome associated with a rectal cancer and adenomatous changes in colonic polyps. Am J Surg Pathol $9: 65-71$, 1985

17）内藤英明，英本忠昭，蒲池寿：結腸澞術後に 見られた Cronkhite-Canada 症候群の1 部検 例。痁の臨 $32: 1619-1624,1986$

18）武田宏司, 斎藤雅雄, 林下尚之ほか：大腸癌を 合併した Cronkhite-Canada 症候群の 1 例. Gastroenterol Endosc 28:1659-1659, 1986

19）高橋賢一，三上勝也，横山慎ほか：直腸滔㧍 よび大腸ポリープの腺腫性変化を伴った Cronkhite-Canada 症候群の 1 手術例. 消外 9:519524,1986

20）荒井秀典，浜島博，木村達ほか：大腸澏を 合併した Cronkhite-Canada 症候群の 1 例. Gastroenterol Endosc $29: 2539-2544,1987$

21）趙 成済，富田富士子，玉本文彦ほか：直腸癌 を合併した Cronkhite-Canada姃候群の 1 例. 臨放射線 $33: 105-108,1988$

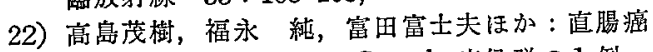
を合併した Cronkhite-Canada 症候群の 1 例一 本邦報告例の集計と考察—. 消外 $14: 363-$ 369,1991

23）久田良览，畑清一郎，田中道夫ほか：Cronkhite-Canada 症侯群的1 例. 皮膚病竛療 13 : 625-628, 1991 


\title{
A Case of Cronkhite-Canada Syndrome Associated with Sigmoid Colon Cancer
}

\author{
M. Itabashi, S. Yamanaka, T. Shiratori and A. Moriuti* \\ Department of Surgery, *Pathology, Oita Almeida Memorial Hospital, Oita \\ S. Kameoka and K. Hamano \\ Department of Surgery II, Tokyo Women's Medical Collegee, Tokyo
}

A 78-year-old women with the characteristic clinical and pathological picture of Cronkhite-Canada Syndrome associated with sigmoid colon cancer is presented.

Upper gastrointestinal endoscopy revealed nearly total replacement of gastric mucosa by numerous polyps. Biopsy specimens of these polyps showed hyperplastic glands without atypia and edematous stroma with inflammatory cell infiltration.

Barium enema study revealed sigmoid colon cancer and semipedunculated polyps. Colonoscopic biopsy was performed for these lesions. Histological findings showed adenocarcinoma and tubular adenomas with mild atypia.

According to our research, fifteen cases of Cronkhite-Canada syndrome associated with colon cancer have been reported in Japan. We added here a case of such a rare condition to the literatures. 